\title{
Ecotoxicological Risk Assessment of Surface Water Receiving Abattoir Effluent
}

\author{
Doris Fovwe Ogeleka ${ }^{1, ~ *}$, Mildred Chukwuedum Emegha ${ }^{1}$, Felix Ebhodaghe Okieimen ${ }^{2}$ \\ ${ }^{1}$ Department of Chemistry, College of Science, Federal University of Petroleum Resources, Effurun, Nigeria \\ ${ }^{2}$ Geo-Environmental and Climate Change Adaptation Research Centre, College of Science, University of Benin, Benin City, Nigeria
}

Email address:

dorysafam@yahoo.com (D.F. Ogeleka),emeghamildred@yahoo.com (M. C. Emegha), felix.okieimen@uniben.edu (F. E. Okieimen)

${ }^{*}$ Corresponding author

\section{To cite this article:}

Doris Fovwe Ogeleka, Mildred Chukwuedum Emegha, Felix Ebhodaghe Okieimen. Ecotoxicological Risk Assessment of Surface Water Receiving Abattoir Effluent. Science Journal of Chemistry. Vol. 9, No. 1, 2021, pp. 14-22. doi: 10.11648/j.sjc.20210901.13

Received: February 9, 2021; Accepted: February 20, 2021; Published: March 3, 2021

\begin{abstract}
Background: This research examined the surface water ecotoxicological risk of untreated abattoir effluent discharged directly into nearby rivers that could result in likely damage to aquatic species. Objective: The study was aimed at evaluating the deleterious ecological effects resulting from discharge of abattoir effluent into surface waters of some selected rivers in Effurun metropolis, Delta State, Nigeria. Method: The American Public Health Association (APHA) standard protocol was used for testing the water quality in addition to the Surface Water Ecotoxicological Risk Assessment Matrix (SW-ERAM), which was used to evaluate the ecological effects. Results: The $\mathrm{pH}$ values ranged from $5.48 \pm 0.14$ (Agbaroh river) to $6.76 \pm 0.18$ (Agbaroh abattoir effluent) indicating a slightly acidic environment. The waters were moderately to highly turbid with values between $10 \pm 1$ NTU and 196.11 \pm 9.0 NTU. Total suspended solids (TSS) were relatively high and varied from $14 \pm 1.0$ (Ugbomro river - control) to $242 \pm 12$ (Ekpan abattoir effluent). Besides the control, the water samples from all the locations showed high levels of total coliform bacteria. The risk level was rated high [5E or $25(\mathrm{~A}, \mathrm{P}, \mathrm{E})]$, which was designated as harmful and capable of affecting aquatic animals (A), plants (P) and the environment (E). Conclusion: The indication from this study is that continuous discharge of untreated abattoir effluent into surface waters may pose threat to aquatic species and human health.
\end{abstract}

Keywords: Abattoir, Ecotoxicological Risk, Effluent, Risk Assessment, Surface Water

\section{Introduction}

The inability of the regulatory agencies - Federal Ministry of Environment (FMEnv) and its subsidiary - National Environmental Standards and Regulations Enforcement Agency (NESREA) to ensure effective management and control of abattoir effluent have resulted in severe ecosystem damage. The damage to environmental resources is as a result of the indiscriminate discharge of untreated abattoir effluent directly into recipient water bodies. The primary effects can be visible on organisms in the environment especially aquatic receptors since the wastes contain contaminants that could impair these species at lethal and sublethal levels. The secondary effects being damage to human health, aesthetics, sanitation and hindrance to economy development of the region / country [1].

The process and practice of killing animals for production of food and packaged products is as old as humanity [2]. An abattoir could be considered as a facility, which is approved and registered by controlling authorities for hygienic slaughtering and processing of meat products for human consumption [3]. Abattoir effluent could be regarded as the waste generated from abattoir activities, such as animal faeces, blood, fat, animal trimmings, paunch content and urine [4]. In Nigeria, abattoirs are often situated close to water bodies due to one or more of the following reasons: easy access to water for washing and other slaughtering process; reduce cost of private water supply systems and ease of disposing effluent. Many abattoirs dispose of wastes directly into rivers or streams and also use water from such sources to wash or clean the slaughtered animals $[5,6]$.

In Nigeria, on site waste management / pretreatment prior to discharge to local drainage is required by environmental laws, however, this is not usually implemented by abattoir users or enforced by appropriate regulatory agencies. Similarly, there are no regulations requiring the treatment of 
abattoir effluent before discharge into the environment usually surface waters [7].

Abattoirs / slaughter houses have reportedly had negative impact on environmental matrices leading to surface water impairment and other environmental alterations [8]. Some research indicating ecological alterations to surface water quality and impacts on aquatic species include works of Ajetunmobi and Ogunfowora [4], who, assessed the negative impacts of abattoir wastes on the physico-chemical parameters of Odo River, Cele Ijesha, Lagos Nigeria and observed some deterioration of the surface water quality. Their observations also showed that continuous release of abattoir effluent into aquatic ecosystem could lead to death of organisms in the water bodies. Similarly, Bandaw and Herago [7], noted in their review on abattoir waste management that due to challenges in disposing, treating and processing abattoir effluent in an environmentally friendly manner, there could be high risk on environmental matrices (underground water, air, soil) and possible public health risks through transmission of diseases to human.

Since, abattoir practices could negatively impact and threatened vulnerable aquatic species, vegetation and human lives (Figure 1), this study was aimed at evaluating the deleterious ecological effects resulting from discharge of abattoir effluent into surface waters of some selected rivers in Effurun metropolis, Delta State using the Surface Water Ecotoxicological Risk Assessment Matrix (SW-ERAM).

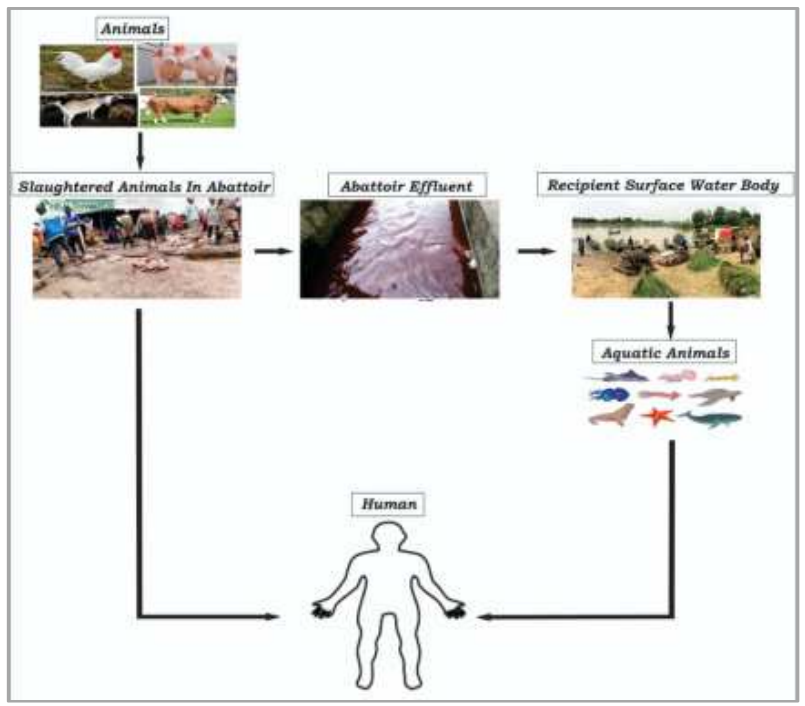

Figure 1. Ecotoxicological interaction of abattoir effluent.

Capsule summary

The SW-ERAM is used to evaluate the deleterious ecological effects of contaminants discharged into surface resources so as to safe guard aquatic organisms and human from diseases and death.

\section{Materials and Methods}

\subsection{Study Area}

The study area was Effurun and its environs in the Niger
Delta ecological zone of Nigeria. The area witnesses a mean monthly rainfall of about $300 \mathrm{~mm}$ (June to October) and lower than $50 \mathrm{~mm}$ (December to March). The occupation of the people include: farming, trading and fishing. Drilling and extraction of fossil fuels also take place in the area.

\subsection{Abattoir Effluent and Surface Water Sampling}

In the locations that had abattoirs an average of twenty five to thirty animals including cows, rams and goats were slaughtered daily. The typical daily abattoir activities in these locations include: slaughtering of the animals, burning / dehairing, hide removal, trimming, washing and cleaning activities. The waste generated composed of animal faeces, blood, fat, animal trimmings, paunch content, urine from operations like lairage, stunning or bleeding, carcass processing etc.

Sampling was undertaken during the rainy season in the month of August 2019. Aggregate river water samples were taken approximately $500 \mathrm{~m}$ (downstream) from the point of discharge of the abattoir effluent from three (3) locations namely Ekpan, Osubi, Agbarho Rivers with intense abattoir activities in Effurun metropolis in Delta State. Similarly, abattoir effluent were collected approximately $200 \mathrm{~m}$ from the point of slaughter before the effluent gets into the river (recipient environment). The effluent from each abattoir runs off through a narrow earthen (unconcreted) channel approximately $200 \mathrm{~m}$ from the river and empties into it. The different abattoirs and the rivers are independent of one another and does not directly flow into each other. In addition, samples were collected from Ugbomro River as control where there was no abattoir activities to determine variations between concentration of the analyzed properties from the contaminated recipient environment and the uncontaminated river.

A total of eighty four (84) samples in replicates from the different locations were collected and analyzed for some physico-chemical characteristics, metals and microbial analysis. The containers used to hold the samples were rinsed three times with the effluent and river waters to be sampled before it was collected. The samples were appropriately preserved by cooling at $4^{\circ} \mathrm{C}$ for the physico-chemical characteristics, while samples for metals and organic analysis was held in 1-2 $\mathrm{mL}$ of 1:1 nitric and sulphuric acid (AR) respectively. Samples for microbial properties were preserved in sodium thiosulphate [9]. The geo references for the sampling locations are captured in Table 1 and Figure 2.

Table 1. Coordinates of sampling locations for abattoir effluent and rivers.

\begin{tabular}{|c|c|c|}
\hline Sampling Area & Latitude & Longitude \\
\hline Ekpan River & 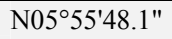 & $\mathrm{E} 005^{\circ} 74^{\prime} 38.9^{\prime \prime}$ \\
\hline Ekpan abattoir effluent & N0554'56.3" & $\mathrm{E} 005^{\circ} 74^{\prime} 61.4^{\prime \prime}$ \\
\hline Osubi River & N05³3'29.6" & $\mathrm{E} 005^{\circ} 47^{\prime} 001^{\prime \prime}$ \\
\hline Osubi abattoir effluent & N05³3'68.8" & $\mathrm{E} 005^{\circ} 47^{\prime} 11.2^{\prime \prime}$ \\
\hline Agbarho River & N05³3'00.1" & $\mathrm{E} 005^{\circ} 50^{\prime} 56.7^{\prime \prime}$ \\
\hline Agbarho abattoir effluent & N05³2'95.2" & $\mathrm{E} 005^{\circ} 52^{\prime} 68.1^{\prime \prime}$ \\
\hline Ugbomro River (control) & N05³3'484" & $\mathrm{E} 005^{\circ} 58^{\prime} 065^{\prime \prime}$ \\
\hline
\end{tabular}




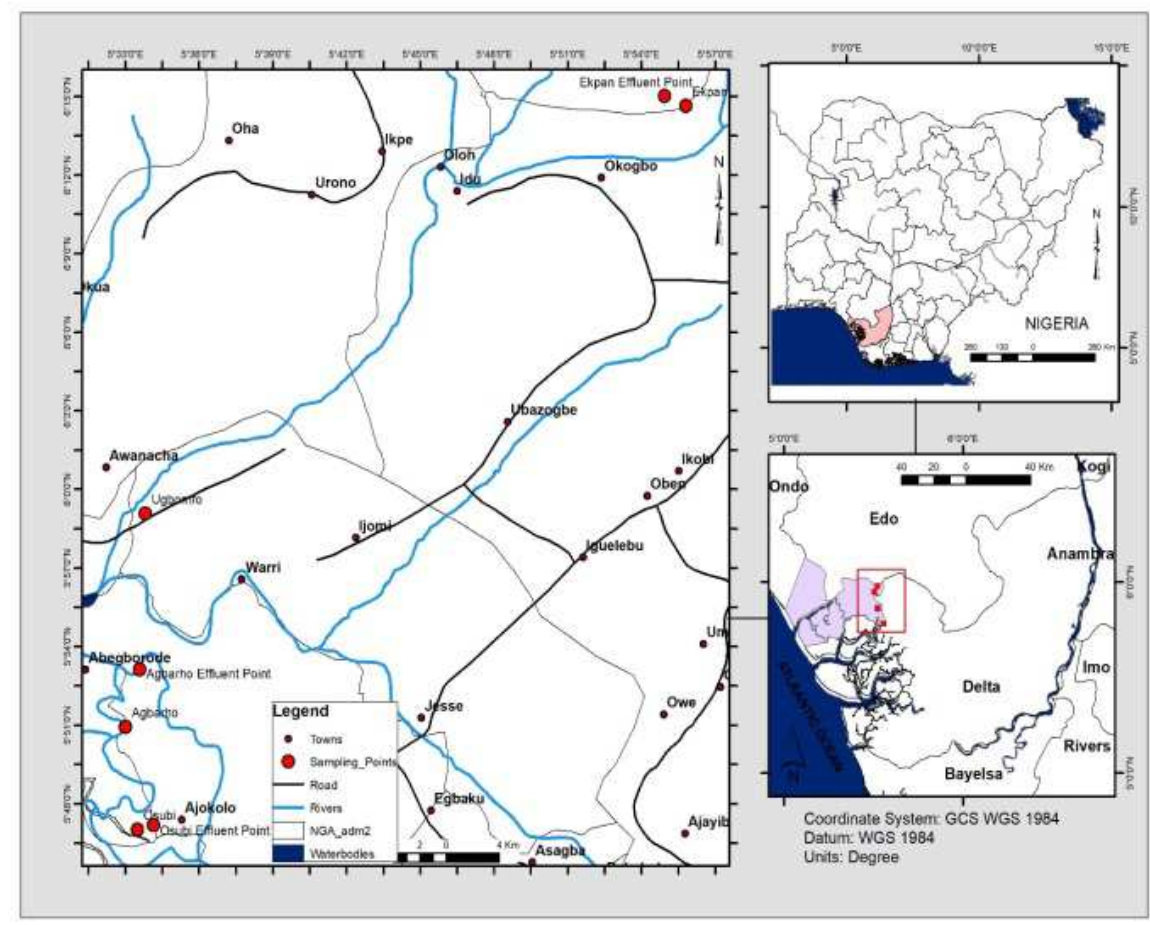

Figure 2. Map of Delta State showing the sampling locations.

\subsection{Methods}

The parameters listed in Table 2 were analyzed to assess the impact of the abattoir effluent on the rivers.

Table 2. Methods for the parameters analyzed in the samples.

\begin{tabular}{|c|c|}
\hline Parameters & Analytical Methods \\
\hline \multicolumn{2}{|l|}{ Physico-chemical } \\
\hline $\mathrm{pH}$ & Electronic method (APHA - 4500- $\mathrm{H}^{+}$) \\
\hline Temperature, ${ }^{\circ} \mathrm{C}$ & Thermometer (APHA, 2550-B) \\
\hline Conductivity, $\mu \mathrm{S} / \mathrm{cm}$ & APHA 2510 B \\
\hline Total dissolved solids (TDS), mg/L & APHA 2540-C \\
\hline Total Suspended Solids (TSS), mg/L & Gravimetric method (APHA-2540-D) \\
\hline Turbidity, NTU & Nephelometric method (APHA - 2130-B) \\
\hline \multicolumn{2}{|l|}{ Anions } \\
\hline Salinity $\left(\mathrm{Cl}^{-}\right), \mathrm{mg} / \mathrm{L}$ & Mohr's Argentometric method (APHA 4500 Cl-B) \\
\hline Nitrate, $\mathrm{mg} / \mathrm{L}$ & Cadmium Reduction method (APHA $-4500 \mathrm{NO}_{3}^{-} \mathrm{E}$ ) \\
\hline Phosphate. $\mathrm{mg} / \mathrm{L}$ & Ascorbic Acid method (APHA-4500 $\mathrm{PO}_{4}{ }^{3-} \mathrm{B}$ ) \\
\hline Sulphate, $\mathrm{mg} / \mathrm{L}$ & Turbidity method (APHA-4500 $\left.\mathrm{SO}_{4}{ }^{2-} \mathrm{E}\right)$ \\
\hline \multicolumn{2}{|l|}{ Gross organics } \\
\hline $\mathrm{BOD}, \mathrm{mg} / \mathrm{L}$ & 5 day method (APHA 5210B) \\
\hline $\mathrm{DO}, \mathrm{mg} / \mathrm{L}$ & APHA - 4500-O C \\
\hline $\mathrm{COD}, \mathrm{mg} / \mathrm{L}$ & Dichromate method (Reflux) (APHA - 5300 B) \\
\hline \multicolumn{2}{|l|}{ Inorganics } \\
\hline Calcium, mg/L & Complexometric Titration method \\
\hline Magnesium, $\mathrm{mg} / \mathrm{L}$ & Complexometric Titration method \\
\hline Metals & Atomic Absorption Spectrophotometer (AAS), (APHA 3400) \\
\hline Total Coliform Bacteria & Multiple Tube Test (APHA 9222A) \\
\hline
\end{tabular}

\subsection{Statistical Analysis}

The results from this study were analyzed using descriptive statistics and ANOVA to test the significant variation between the controls and different rivers at a probability level of $5 \%$.

\section{Results}

Tables 3 to 5 and Figure 3 displayed the results of the analysis for the abattoir effluent and the receiving rivers. The results were benched marked against the World Health Organization (WHO) prescribed limits for abattoir activity 
with the view of finding the deviation or non-conformance from the acceptable standards [10]. This was used to determine if the abattoir effluent discharged directly into rivers has influence on the surface water quality to the extent that it may be injurious to aquatic lives and human health.

\subsection{Abattoir Effluent and Surface Water Characteristics}

The average $\mathrm{pH}$ values obtained varied from $5.48 \pm 0.14$ to $6.76 \pm 0.18$, with some of the analyzed samples have $\mathrm{pH}$ values below the WHO standard of 6.5 - 8.5 (Osubi River $5.70 \pm 0.13$ and Agbarho River - 5.48 \pm 0.14 ). The temperature of the samples ranges from $28.2{ }^{\circ} \mathrm{C} \pm 1$ to $29.8{ }^{\circ} \mathrm{C} \pm 2$, a temperature of less than $40{ }^{\circ} \mathrm{C}$ is prescribed by the regulators. Total Dissolved Solid (TDS) concentrations ranges from $30 \pm 0.82 \mathrm{mg} / \mathrm{L}$ to $1338 \pm 32 \mathrm{mg} / \mathrm{L}$. Similarly, salinity concentrations range from $12.5 \pm 0.7 \mathrm{mg} / \mathrm{L}$ to $461 \pm 14$ $\mathrm{mg} / \mathrm{L}$. As in salinity and TDS, all the abattoir effluent samples had concentrations above the recommended limit of 250 and $500 \mathrm{mg} / \mathrm{L}$ respectively.

Total Suspended Solid (TSS) values varied between $14 \pm 1$ $\mathrm{mg} / \mathrm{L}$ and $242 \pm 12 \mathrm{mg} / \mathrm{L}$ with Ekpan, Osubi and Agbaroh discharge points above the WHO limit of $30 \mathrm{mg} / \mathrm{L}$. The turbidity results for all the samples did not comply with the WHO permissible limit of 1.0 NTU. Sulphate values for analyses samples ranges from $1.3 \pm 0.06 \mathrm{mg} / \mathrm{L}$ to $314 \pm 13$ $\mathrm{mg} / \mathrm{L}$. The sulphate values obtained for all the analyzed samples were within the $450 \mathrm{mg} / \mathrm{L}$ standard limits. Other nutrients like phosphate had concentrations ranging from $1.75 \pm 0.02$ to $620.5 \pm 16 \mathrm{mg} / \mathrm{L}$ ), All values obtained for phosphate were above WHO permissible limit of $1 \mathrm{mg} / \mathrm{L}$. Nitrates ranged from $2.2 \pm 0.1$ to $93 \pm 6 \mathrm{mg} / \mathrm{L}$ with Ekpan and Osubi discharge point having a nitrate values of $93 \pm 6$ and $90.8 \pm 5$ respectively, which is above the WHO limit of 50 $\mathrm{mg} / \mathrm{L}$.

Dissolved oxygen (DO) levels ranged from $0.23 \pm 0.03$ to $6.4 \pm 0.25 \mathrm{mg} / \mathrm{L}$. The DO showed compliance with the WHO standards ranging from $5 \mathrm{mg} / \mathrm{L}$ in the river waters but nonconformance in the abattoir effluent. The biochemical oxygen demand (BOD) values obtained ranged from $1.79 \pm 1.2$ to $1021 \pm 30 \mathrm{mg} / \mathrm{L}$, which is above the WHO limits of $20 \mathrm{mg} / \mathrm{L}$ for wastewater indicating pollution in the sampled waters.

\subsection{Surface Water Characteristics of Rivers Receiving Abattoir Effluent}

The results of the rivers receiving abattoir effluent also displayed in Table 3 and Figures $3-4$ indicated that the abattoir effluent had some adverse effect on the surface water quality. Parameters such as $\mathrm{pH}$, TSS, turbidity, total iron and microbial analysis recorded non-conformances with the WHO limits used to bench mark the water quality. While the pH of Osubi and Agbarho Rivers were slightly acidic, there was microbial presence in the surface waters, which implied that the river waters had coliform bacteria above the recommended limit of nil (0). The presence of microbial community / colonies could likely influence / impact the water quality with disease-causing bacteria that could affect aquatic species and subsequently humans.

Ekpan, Osubi and Agbaroh rivers had relatively high concentration of heavy metals which often times deteriorate the surface water quality, makes it unfit for certain purposes and poses great danger to aquatic lives. The heavy metals can cause inhibitory effect on the development of aquatic organisms, hatching delay, reduction in oxygen level and mortality [11].

Table 3. Mean results of abattoir effluent from the study locations.

\begin{tabular}{|c|c|c|c|c|}
\hline Parameters & WHO limit & Ekpan Abattoir effluent & Ekpan River & Osubi Abattoir effluent \\
\hline \multicolumn{5}{|l|}{ Physico-chemicals } \\
\hline $\mathrm{pH}$ & $6.5-8.5$ & $6.71 \pm 0.23$ & $6.42 \pm 0.13$ & $6.68 \pm 0.27$ \\
\hline Temperature, ${ }^{\circ} \mathrm{C}$ & $<40^{\circ} \mathrm{C}$ & $29.5 \pm 1.0$ & $28.2 \pm 1.0$ & $29.4 \pm 2.0$ \\
\hline Conductivity, $\mu \mathrm{S} / \mathrm{cm}$ & $1200 \mu \mathrm{s} / \mathrm{cm}$ & $2629 \pm 49$ & $350 \pm 12$ & $2240 \pm 43$ \\
\hline $\mathrm{TDS}, \mathrm{mg} / \mathrm{L}$ & $500 \mathrm{mg} / \mathrm{L}$ & $1338 \pm 32$ & $175 \pm 9.3$ & $1121 \pm 23$ \\
\hline Salinity, mg/L & $250 \mathrm{mg} / \mathrm{L}$ & $461 \pm 14$ & $77.9 \pm 2.7$ & $456 \pm 18$ \\
\hline $\mathrm{TSS}, \mathrm{mg} / \mathrm{L}$ & $30 \mathrm{mg} / \mathrm{L}$ & $242 \pm 12$ & $20 \pm 1.0$ & $104 \pm 9$ \\
\hline Nitrate $(\mathrm{mg} / \mathrm{L})$ & $50 \mathrm{mg} / \mathrm{L}$ & $93 \pm 6.0$ & $33 \pm 1.0$ & $90.8 \pm 5.0$ \\
\hline Phosphate (mg/L) & $1 \mathrm{mg} / \mathrm{L}$ & $52.2 \pm 1.4$ & $7.14 \pm 0.5$ & $50 \pm 2.4$ \\
\hline Sulphate (mg/L) & $450 \mathrm{mg} / \mathrm{L}$ & $314 \pm 13$ & $22 \pm 0.8$ & $249.8 \pm 11$ \\
\hline \multicolumn{5}{|l|}{ Gross organics } \\
\hline $\mathrm{BOD}, \mathrm{mg} / \mathrm{L}$ & $20 \mathrm{mg} / \mathrm{L}$ & $680.50 \pm 18$ & $1.79 \pm 1.2$ & $430.85 \pm 14$ \\
\hline $\mathrm{DO}, \mathrm{mg} / \mathrm{L}$ & $5 \mathrm{mg} / \mathrm{L}$ & $0.23 \pm 0.03$ & $6.4 \pm 0.25$ & $1.8 \pm 0.43$ \\
\hline $\mathrm{COD}, \mathrm{mg} / \mathrm{L}$ & $\mathrm{N} / \mathrm{A}$ & $1051 \pm 32$ & $2.44 \pm 0.3$ & $915.74 \pm 28$ \\
\hline Magnesium, mg/L & N/A & $96 \pm 6.0$ & $24 \pm 1.1$ & $124 \pm 8.0$ \\
\hline Potassium, mg/L & $\mathrm{N} / \mathrm{A}$ & $66.11 \pm 2.2$ & $25.37 \pm 1.0$ & $108 \pm 7.0$ \\
\hline Iron $(\mathrm{mg} / \mathrm{L})$ & 1.0 & $172.8 \pm 12$ & $17.16 \pm 1.2$ & $80.3 \pm 3.0$ \\
\hline Copper (mg/L) & N/A & $0.082 \pm 0.007$ & $0.071 \pm 0.02$ & $5.20 \pm 0.14$ \\
\hline Cadmium (mg/L) & $\mathrm{N} / \mathrm{A}$ & $0.102 \pm 0.01$ & $0.079 \pm 0.02$ & $0.088 \pm 0.01$ \\
\hline \multicolumn{5}{|l|}{ Microbial } \\
\hline Total coliform, MPN/100 mL & 0 & $24 \pm 2$ & $14 \pm 1$ & $20 \pm 2$ \\
\hline
\end{tabular}


Table 3. Continued.

\begin{tabular}{|c|c|c|c|c|}
\hline Parameters & Osubi River & Agbaroh Abattoir effluent & Agbaroh River & Ugbomro River - Control \\
\hline \multicolumn{5}{|l|}{ Physico-chemicals } \\
\hline $\mathrm{pH}$ & $5.70 \pm 0.13$ & $6.76 \pm 0.18$ & $5.48 \pm 0.14$ & $6.57 \pm 0.12$ \\
\hline Temperature, ${ }^{\circ} \mathrm{C}$ & $28.3 \pm 1.0$ & $28.5 \pm 1.0$ & $29.8 \pm 1.0$ & $29.8 \pm 2.0$ \\
\hline Conductivity, $\mu \mathrm{S} / \mathrm{cm}$ & $60 \pm 1.9$ & $2198 \pm 56$ & $68 \pm 2.0$ & $63 \pm 1.8$ \\
\hline $\mathrm{TDS}, \mathrm{mg} / \mathrm{L}$ & $30 \pm 0.82$ & $1105 \pm 27$ & $34 \pm 0.94$ & $31 \pm 0.78$ \\
\hline Salinity, mg/L & $12.9 \pm 0.6$ & $327 \pm 12$ & $14.9 \pm 0.8$ & $12.5 \pm 0.7$ \\
\hline $\mathrm{TSS}, \mathrm{mg} / \mathrm{L}$ & $16 \pm 1.0$ & $212 \pm 14$ & $18 \pm 1.1$ & $6 \pm 1.0$ \\
\hline Turbidity, NTU & $14.81 \pm 1.0$ & $146.11 \pm 8.0$ & $22 \pm 1.2$ & $4 \pm 1.0$ \\
\hline Nitrate (mg/L) & $2.6 \pm 0.01$ & $79.8 \pm 3.0$ & $10.4 \pm 0.6$ & $2.2 \pm 0.10$ \\
\hline Phosphate $(\mathrm{mg} / \mathrm{L})$ & $6.4 \pm 0.04$ & $620.50 \pm 16$ & $1.75 \pm 0.20$ & $1.75 \pm 0.02$ \\
\hline Sulphate $(\mathrm{mg} / \mathrm{L})$ & $7.8 \pm 0.08$ & $1.3 \pm 0.06$ & $6.9 \pm 0.27$ & $6.8 \pm 0.27$ \\
\hline \multicolumn{5}{|l|}{ Gross organics } \\
\hline BOD, $\mathrm{mg} / \mathrm{L}$ & $2.55 \pm 0.10$ & $1021 \pm 30$ & $2.54 \pm 0.89$ & $1.75 \pm 0.03$ \\
\hline $\mathrm{DO}, \mathrm{mg} / \mathrm{L}$ & $5.4 \pm 0.83$ & $0.43 \pm 0.02$ & $5.82 \pm 0.70$ & $6.33 .10 \pm 18$ \\
\hline $\mathrm{COD}, \mathrm{mg} / \mathrm{L}$ & $6.98 \pm 0.80$ & $1408 \pm 23$ & $6.48 \pm 0.53$ & $3.75 \pm 0.43$ \\
\hline \multicolumn{5}{|l|}{ Inorganics } \\
\hline Calcium, mg/L & $4.00 \pm 0.4$ & $134 \pm 9.0$ & $8 \pm 0.2$ & $8 \pm 0.2$ \\
\hline Magnesium, $\mathrm{mg} / \mathrm{L}$ & $2 \pm 0.02$ & $48 \pm 4.0$ & $4 \pm 0.1$ & $2 \pm 0.02$ \\
\hline Potassium, mg/L & $2.54 \pm 0.04$ & $40.7 \pm 2.8$ & $2.6 \pm 0.2$ & $2.5 \pm 0.01$ \\
\hline Iron $(\mathrm{mg} / \mathrm{L})$ & $16.8 \pm 1.0$ & $37.09 \pm 3.0$ & $8.53 \pm 1.0$ & $3.76 \pm 0.21$ \\
\hline Copper $(\mathrm{mg} / \mathrm{L})$ & $0.530 \pm 0.01$ & $0.44 \pm 0.02$ & $0.102 \pm 0.02$ & $0.048 \pm 0.02$ \\
\hline Cadmium $(\mathrm{mg} / \mathrm{L})$ & $0.068 \pm 0.01$ & $0.096 \pm 0.02$ & $0.055 \pm 0.01$ & $0.012 \pm 0.03$ \\
\hline \multicolumn{5}{|l|}{ Microbial } \\
\hline Total coliform, MPN/100 mL & $15 \pm 1$ & $32 \pm 4$ & $8 \pm 1$ & 0 \\
\hline
\end{tabular}

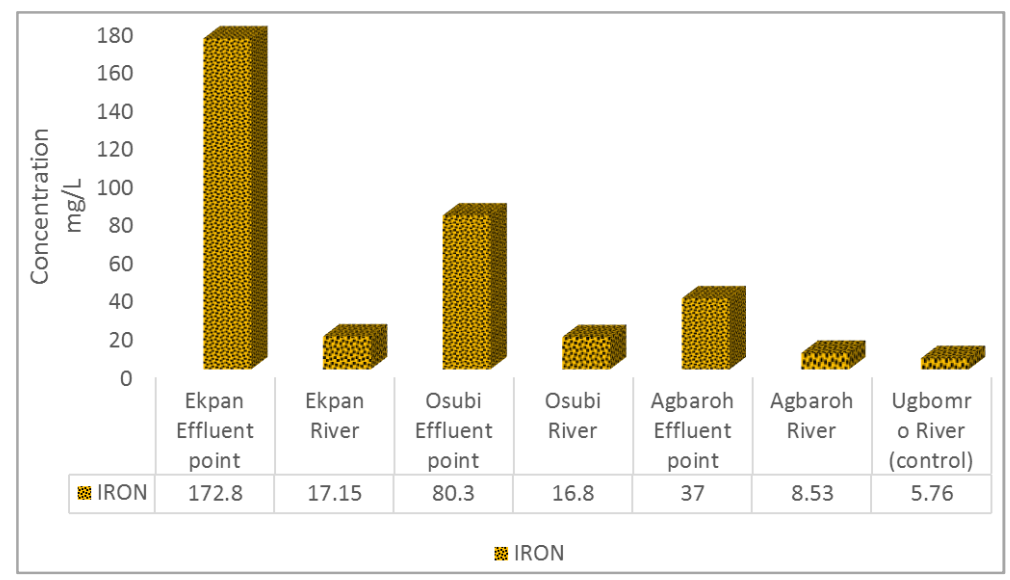

Figure 3. Average results of Iron for the contaminated sites.

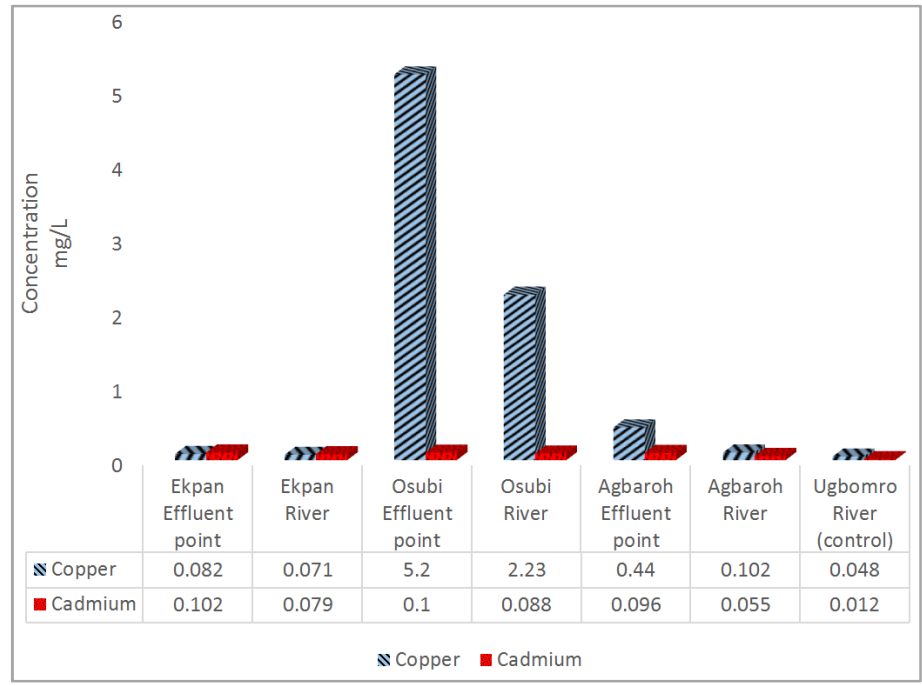

Figure 4. Average results of copper and cadmium for the contaminated sites. 


\subsection{Risk Assessment for Surface Water Quality}

On the Surface Water Ecotoxicological Risk Assessment Matrix (SW-ERAM), risk levels can be classified as low, moderate, medium, high or very high (Table 4). An organism (pelagic or bottom settlers) in the water may be affected depending on the water quality, exposure and the pollution considered for classification include: exposure, safety consideration, indicator for water utilization and water quality amongst others. The risk levels are categorized in a numbered format $[12,13]$. Each hazard is given a rating, and this was multiplied by the probability that these hazards would occur using the relationship:

Risk level = Hazard severity $\mathrm{x}$ likelihood (probability) of consumption (Table 4).

Hazard severity are rated as 1 (practically not harmful), 2 (slightly harmful), 3 (considerably harmful), 4 (very harmful) and 5 (extremely harmful). Similarly, the likelihood or probability of consumption are rated as 1 (seldom - A - yearly), 2 (frequent - B - quarterly), 3 (very likely - C monthly). 4 (near certain - D - weekly) and 5 (certain - E daily) (Table 4) $[12,13]$.

For example rated on a scale of 10 , if 7 parameters analyzed complied with the regulatory limits means that:

Percentage conformance $=7 / 10 * 100=70 \%$,

From the rating on conformance it would be classified as medium risk. Thus, if the species are exposed to such waters daily which is a probability of 5 or $\mathrm{E}$ and the conformance is $70 \%$ having a hazard severity of 2 (Table 4 ), then the,

Risk level $=$ hazard severity $\mathrm{x}$ likelihood (probability of consumption) $=2 \times 5(\mathrm{E})=10$ or $2 \mathrm{E}$ and the risk level is medium.

Similarly, it also implies that for a $0 \%$ conformance and daily exposure, the risk level would be high, which is Risk level = hazard severity (5) x (probability of exposure) $5(\mathrm{E})=25$ or $5 \mathrm{E}$

However, since it is affecting aquatic animals (A), plants $(\mathrm{P})$ and environment (E), it would be classified as $5 \mathrm{E}(\mathrm{A}, \mathrm{P}, \mathrm{E})$.

Table 4. Surface Water Ecotoxicological Risk Assessment Matrix (SW-ERAM).

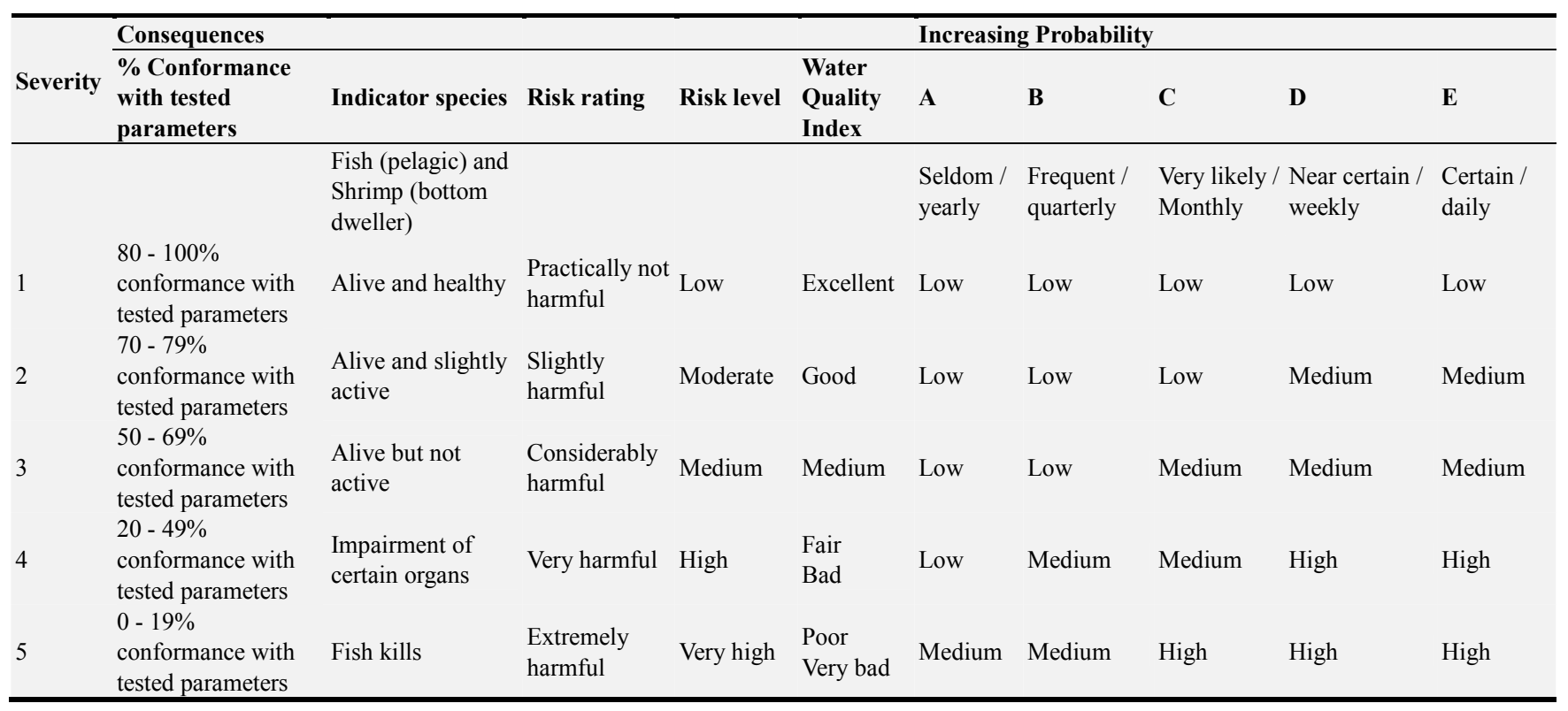

Data extracted from Ogeleka et al., [13]; WQI = Source: Javid et al., [14]

The following is a guide as to precautions to be taken when discharging effluent into receiving water bodies

$1 \times 5=5=$ Low - adjudged suitable for aquatic organisms

$2 \times 5=10=$ Moderate- not suitable for aquatic organism

$3 \times 5=15=$ Medium - not suitable for aquatic organisms

$4 \times 5=20=$ High - not suitable for aquatic organisms would lead to damage in species vital organs

$5 \times 5=25=$ Very high (extreme) - not suitable for aquatic resources would lead to fish kill and other aquatic organisms

\subsection{Surface Water Consumption Risk Assessment Matrix (SW-CRAM)}

Assessing the level of risk associated with the daily discharge of abattoir effluent on recipient rivers was done using the surface water consumption risk assessment matrix (SW-CRAM). The water quality of the abattoir effluent were adjudged bad with the quality of the Rivers categorized medium with only Ugbomro River with no abattoir activity rated 'good'. The risk rating was extremely harmful for the effluent and considerably harmful in the rivers (Table 5). The risk level of daily effluent discharge into recipient rivers was rated high [5 $\mathrm{E}$ or 25] and could affect animals (A), people (P) and the environment (E), thus designated as $5 \mathrm{E}$ or 25 (A, $P$, E) [6]. 
Table 5. Risk level using the surface water consumption risk assessment matrix (SW-CRAM).

\begin{tabular}{llll}
\hline & Ekpan abattoir effluent & Ekpan River & Osubi abattoir effluent \\
\hline No of parameters analyzed & 16 & 16 & 10 \\
No of parameters with conformance & 6 & 62.5 & 7 \\
\% Conformance with tested parameters & 37.5 & Medium & Medium \\
Water Quality Category & Bad & High & Considerably harmful \\
Risk level & Extremely harmful & Bad E or 15 (A, P, E) \\
Risk rating & 5 E or 25 (A, P, E) & High \\
Risk level for daily exposure & & Extremely harmful E or 25 (A, P, E) \\
\hline
\end{tabular}

Table 5. Continued.

\begin{tabular}{|c|c|c|c|c|}
\hline & Osubi River & Agbarho abattoir effluent & Agbarho River & Ugbomro River \\
\hline No of parameters analyzed & 16 & 16 & 16 & 16 \\
\hline No of parameters with conformance & 10 & 6 & 11 & 12 \\
\hline$\%$ Conformance with tested parameters & 62.5 & 37.5 & 68.75 & 75 \\
\hline Water Quality Category & Medium & $\mathrm{Bad}$ & Medium & Good \\
\hline Risk level & Medium & High & Medium & Moderate \\
\hline Risk rating & Considerably harmful & Extremely harmful & Considerably harmful & Slightly Harmful \\
\hline
\end{tabular}

The WHO acceptable limits was used for rating the risk level for the parameters with limits.

\section{Discussion}

$\mathrm{pH}$ plays a significant role in determining diversity and bacteria population growth in surface waters. Microorganisms most often change the $\mathrm{pH}$ of the habitat they live in by producing acidic or basic metabolic wastes. If the environment of their activity become acidic, it could result in acidosis and affect non-tolerant aquatic species residing in such medium. The results from this appraisal compared favourably with the works of Adelowo et al., [15], who reported a range of 5.7-6.7 in their study. The temperature range in this appraisal falls within the WHO standard of permissible limit of less than $40{ }^{\circ} \mathrm{C}$. It is worthy to note that temperature influences the survival of aquatic organisms, whether low or high. The range of temperature obtained are similar to those reported by Magaji and Chup [16], who identified in his study that most abattoir area have temperature within $25^{\circ} \mathrm{C}$ to $28.8^{\circ} \mathrm{C}$.

High level of TDS is caused by the presence of chlorides, potassium and sodium amongst others. This interferes with the taste of the waters making them less desirable to consume with significant bitter sweet taste. Njoku-Tony et al., [8], reported that TDS could pose a variety of health hazard to living organisms. In the same view, high chemical oxygen demand (COD) level indicates the presence of chemical oxidants in the samples and these can impact the water quality at certain concentration thus affecting the ultimate survival of aquatic species. Chemical oxygen demand (COD) has an inverse relationship with the level of biochemical oxygen demand (BOD) that is amount of dissolved oxygen consumed by the water organisms [17]. Microorganisms use up dissolved oxygen for their metabolic functions and concentrations less than $2 \mathrm{mg} / \mathrm{L}$ could result in fish kills. A fish kill happens when a large number of fish in an environment die off for a number of reasons. However, dissolved oxygen depletion is a major factor responsible for the death of aquatic species. When a water body is over productive, the oxygen in the water may get used up faster than it can be replenished, which occurs when the water body is overstocked with organisms or if there is a large algal bloom especially in eutrophic waters having high concentrations of nutrients (particularly phosphorus and nitrogen). Fish and other pelagic species need at least 4 to 5 $\mathrm{mg} / \mathrm{L}$ of DO to survive. Dissolved oxygen (DO) is used to assess the degree of pollution by organic components, destruction of organic substances as well as self-purification capability of water bodies. Adequate concentration of dissolved oxygen is vital to sustaining aquatic life and aesthetics of surface waters (rivers, streams, lake) [6, 14]. Like BOD, dissolved oxygen is very crucial in water quality assessment. The more the organic load in a river, the higher the BOD and the lower the DO, this study reported results in agreement with the study of Ojekunle et al [18].

High concentration of nitrate in the water body can lead to nutrient pollution as higher concentrations can cause gastro intestinal tract problems and "blue baby syndrome". Nutrient values above WHO permitted limits can lead to the excessive vegetative growth in the water body (eutrophication) due to excess nutrients for the microorganisms as noted earlier [19]. High levels of nutrients fuel algae blooms, which can initially boost dissolved oxygen levels and subsequently depletes its amount drastically (anoxia) to the detriment of the aquatic species. High total iron concentrations could be due to influx of the waste blood being carried as runoffs into the receiving rivers. The presence of turbidity and colour can also influence the iron content as noted in works by Kruawal et al., [20], which also agrees with this research outcome.

The most common microbial pollutants in effluent are bacteria, which causes a myriad of infections including diarrhoea, dysentery, typhoid, cholera etc. The presence of 
pathogens in the rivers was an indication that the surface water quality was impaired. Total coliform presence in the rivers could be attributed to the indiscriminate release of the abattoir waste, which contained significant amount of the slaughtered animal faeces. The results obtained corroborated that of other previous studies $[2,3,21]$.

\section{Conclusion}

This study concluded that the daily discharge of untreated abattoir effluent into recipient water bodies could negatively impair the physico-chemical and microbial characteristics / quality of aquatic resources as indicated using the SWERAM. The effluent quality from the sampled locations were categorized bad and extremely harmful with the rivers having medium risk and rated considerably harmful and this could ultimately affect aquatic biota. This is a major concern since the rivers could be considered unsafe for aquatic lives, as well as for recreational and domestic activities. With no proper regulatory surveillance, the discharge of untreated abattoir waste may continue unabated. Habitual practice of this nature and similar activities could lead to the death or extinction of certain vulnerable aquatic species and deteriorate the entire ecosystem.

Thus, regulatory authorities should enforce the enacted laws protecting aquatic pollution such that the abattoir effluent are properly treated and managed. Similarly, an aggressive public awareness and enlightenment on possible impacts of surface water pollution from abattoir waste should be embarked upon by relevant agencies. In addition, safe disposal, treatment and processing methods like landfill, composting, incineration, anaerobic digestion and blood processing are highly important ways to manage and get economic benefits from abattoir wastes / by-products instead of direct exposure that would lead to environmental pollution and public health risks.

\section{Authors' Contributions}

The research was carried out in collaboration between all authors. Doris Fovwe Ogeleka and Felix Ebhodaghe Okieimen designed the study, wrote the first draft and performed the statistical analysis. Mildred Chukwuedum Emegha managed the literature search and analysis. All authors read and approved the final manuscript.

\section{Conflict of Interest}

The authors declare no conflict of interest.

\section{Acknowledgements}

The authors wishes to acknowledge members of the GeoEnvironmental and Climate Change Adaptation Research Centre thematic group for their contributions and statistical analysis.

\section{References}

[1] Singh A. L., Jamal S., Baba S. A. \& Islam M. M (2014). Environmental and health impact from slaughterhouse located on the city outskirts: A case study of Turag slaughter house. Journal of Environmental Protection. 5, 556 - 575. DOI: http://dx.doi.org/10.4236/jep.2014.56058.

[2] Asibor G. (2019). Status of discharged abattoir effluent and its effects on the physico-chemical characteristics of Orogodo River, Delta State, Nigeria. International Journal of Environment and Pollution Research. 7 (3), 34-44. DOI: ISSN: 2056-7545.

[3] Oluwawemimo A. O., Adedamola J., Olanike A. \& Eniola K. (2016). Potential bacterial zoonotic pathogens isolated from a major abattoir and its receiving surface water in Abeokuta, Nigeria. Alexandria Journal of Veterinary Sciences. 50 (1), 94-98. DOI: 10.5455/ajvs.222912.

[4] Ajetunmobi A. O. \& Ogunfowora A. O. (2014). Negative impacts of abattoir wastes on the physico-chemical parameters of Odo River, Cele Ijesha, Lagos Nigeria. IOSR Journal of Environmental Science, Toxicology and Food Technology. 8 (1), 9-12. DOI: ISSN: 2319-2399.

[5] Aniebo A. O., Wekh S. N. \& Okoli I. C. (2009). Abattoir blood waste generation in Rivers State and its environmental implications in the Niger Delta. Toxicological \& Environmental Chemistry. $91 \quad$ (4), 619-625. DOI: https://doi.org/10.1080/02772240802343404.

[6] Elemile O. O., Raphael D. O., Omole D. O., Oloruntoba E. O., Ajayi E. O. \& Ohwavborua N. A. (2019). Assessment of the impact of abattoir effluent on the quality of groundwater in a residential area of Omu-Aran, Nigeria. Environ Sci Eur. 31 (16), 1-10. DOI: https://doi.org/10.1186/s12302-019-0201-5.

[7] Bandaw T. \& Herago T. (2017). Review on abattoir waste management. Global Veterinaria. 19 (2), 517 - 524. DOI: 10.5829/idosi.gv.2017.517.524.

[8] Njoku-Tony R. F., Ogbuagu D. H., Ihejirika C. E., Nwoko C. O., Amaku G. E., Azoro V. A., Ukaegbu K., Ezikeudu E. C. \& Edafienene E. O. (2018). Impact of abattoir waste on the water quality of Amilimocha River Asaba, Delta State. International Journal of Energy and Environmental Research. 6 (1) 25-35. DOI: ISSN 2055-0200 (Online).

[9] American Public Health Association/American Water Works Association/Water Environment Federation (2017). Standard methods for the examination of water and wastewater. $23^{\text {rd }}$ edn, Washington DC, USA.

[10] World Health Organization (WHO) (2017). Guidelines for drinking-water quality. WHO Press. Geneva, Switzerland. Fourth edition.

[11] Adesina A. O., Ogunyebi A. L., Fingesi T. S. \& Oludoye O. O. (2018). Assessment of Kara abattoir effluent on the water quality of Ogun River, Nigeria. J. Appl. Sci. Environ. Manage. 22 (9), 1465-1470. DOI: https://dx.doi.org/10.4314/jasem.v22i9.17.

[12] United State Environmental Protection Agency (USEPA). Ecological Risk Assessment Supplemental Guidance Interim Draft. Scientific Support Section Superfund Division EPA Region 4. 2015. 
[13] Ogeleka D. F., Onwuemene C. \& Okieimen F. E. (2017). Toxicity potential of Grassate ${ }^{\circledR}$ a non-selective herbicide on snail (Achachatina marginata) and earthworm (Aporrectodea longa). Chemistry and Ecology. 33 (5), 446 - 462. DOI: https://doi.org/10.1080/02757540.2017.1320393.

[14] Javid A., Yaghmaeian K., Ahbasi E. \& Roudbari A. (2014). An evaluation of water quality from Mojen River by NSFWQI index. Journal of Ecological Engineering. 15 (4), 1-6. DOI: 10.12911/22998993.1125451.

[15] Adelowo O. O., Akinlabi I. A. \& Fagade O. E. (2012). Environmental impact assessment of Attenda abattoir, Ogbomoso southwestern Nigeria on surface and groundwater quality using geo-electrical imaging and microbiological analysis. Environ Monit Assess. 84 (7), 4565-4574. DOI: 10.1007/s10661-011-2285-2.

[16] Magaji J. Y. \& Chup C. D. (2012). The effect of abattoir waste in Gwagwalada, Abuja, Nigeria. Ethiopian Journal of Environmental Studies and Management. 5 (4) (suppl. 2), 542 - 549. DOI: http://dx.doi.org/10.4314/ejesm.v5i4.S14.

[17] Chukwu O. (2008). Analysis of groundwater pollution from abattoir waste in Minna, Nigeria. Research Journal of Dairy $\begin{array}{lllll}\text { Sciences. } & 2 & \text { (4), } & \text { 74-77. } & \text { DOI: }\end{array}$ https://medwelljournals.com/abstract/?doi=rjdsci.2008.74.77.

[18] Ojekunle O. Z. \& Lateef S. T. (2017). Environmental impact of abattoir waste discharge on the quality of surface water and ground water in Abeokuta. Journal of Environmental and Analytical Toxicology. 7 (509), 1-6. DOI: 10.4172/21610525.1000509.

[19] Paerl H. W., Valdes L. M., Peierls B. L., Adolf J. E. \& Harding L. W. (2006). Anthropogenic and climatic influences on the eutrophication of large estuarine ecosystems. Limnology and oceanography. 51 (1), 448-462. DOI: https://doi.org/10.4319/1o.2006.51.1_part_2.0448.

[20] Kruawal K., Sacher F., Werner A., Miller J. \& Knepper T. P. (2005). Chemical water quality in Thailand and its impacts on the drinking water production in Thailand. Science of the Total Environment. 340, 57-70. DOI: 10.1016/j.scitotenv.2004.08.008.

[21] Igbinosa I. H. \& Uwidia I. E. (2018). Effect of abattoir effluents on the physicochemical properties of a receiving watershed in an urban community. Ife J Sci. 20 (2), 219-228. DOI: 10.4314/ijs.v20i2.2.

\section{Biography}

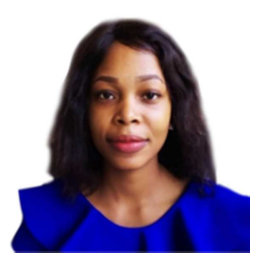

Mildred Chukwuedum Emegha is a researcher in the Department of Chemistry, Federal University of Petroleum Resources Effurun, Nigeria. She has vast knowledge and research interests in environmental studies including Biofilter technology, rural water purification, water sanitation and sustainability, soil, sediment, chemical forensic investigation and toxicology, aquatic / phytotoxicity and ecological risk assessment.

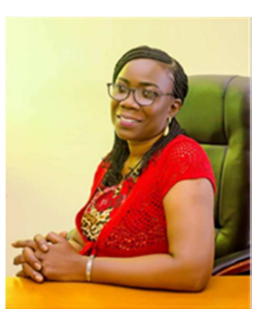

Doris Fovwe Ogeleka is an Associate Professor of Ecotoxicology and Analytical / Environmental Chemistry and a lecturer in the Department of Chemistry, Federal University of Petroleum Resources Effurun, Nigeria. She has vast knowledge and interest in the following research areas which includes: Ecotoxicology / phyto-toxicity, air, water, soil \& sediment chemistry, Ecological Risk Assessment, water sanitation and sustainability, water quality assessment / purification, water consumption risk assessment, chemical forensic assessment, Laboratory Quality Assurance and Quality Control (QA/QC) and waste management techniques amongst others.

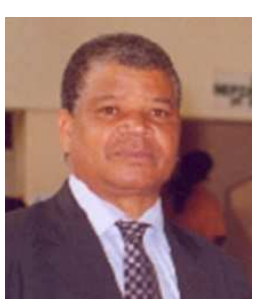

Felix Ebhodaghe Okieimen is a lecturer in the Department of Chemistry, University of Benin, Benin City with background training in Material Chemistry. His research interests include Chemistry of Renewable Materials, Environmental Studies, Biomass and Bioenergy, Nanochemistry etc. $\mathrm{He}$ is the coordinator of the multi-disciplinary training and research programs in the GeoEnvironmental \& Climate Change Adaptation Research Centre and the Centre for Biomaterials Research at the University of Benin. 